\title{
Tectonometamorphic features of geological units along the northern periphery of the Moldanubian Zone (Bohemian Massif)
}

\author{
Kryštof VERNER ${ }^{1,3^{*}}$, David BURIÁNEK², Stanislav VRÁNA ${ }^{1}$, Lukáš VONDROVIC ${ }^{1,3}$, Jaroslava \\ PERTOLDOVÁ', Pavel HANŽL², Radmila NAHODILOVÁ \\ ${ }^{1}$ Czech Geological Survey, Klárov 3, 11821 Prague 1, Czech Republic; krystof.verner@geology.cz \\ ${ }^{2}$ Czech Geological Survey, Leitnerova 22, 65859 Brno, Czech Republic \\ ${ }^{3}$ Institute of Petrology and Structural Geology, Charles University, Albertov 6, 12843 Prague 2, Czech Republic \\ ${ }^{*}$ Corresponding author
}

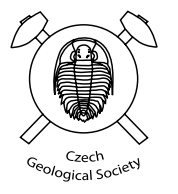

In this paper are reviewed structural, petrological and geochronological data from the main units at the NE periphery of the Moldanubian Zone, i.e. Kutná Hora Complex, Svratka Unit, Polička and Zábřeh units, as well as the Strážek Unit of the Moldanubian Zone. In this domain of the Bohemian Massif, the lower- and upper-crustal units are dominated by metamorphic fabrics produced during the Variscan orogeny.

The mid- to upper-crustal Svratka, Polička and Zábřeh units are affected by $\sim$ MP/MT "long-lived“ ( 350-339 Ma) tectonometamorphic event reflecting $\sim$ WNW-ESE right-lateral strike-slip shearing (transpressional to transtensional tectonics). These regional fabrics are in the Polička and Zábřeh units related with syn-tectonic emplacement and crystallization of calc-alkaline intrusions (Zábřeh Intrusive Complex, Miřetín nad Budislav plutons). In the three structurally high units in the Kutná Hora Complex, Orlice-Sněžník and the Strážek units the strike-slip, "long-lived“ tectonics is rather localized; the high-pressure, high-temperature events followed by heterogeneous and polyphase exhumation of deep-seated rocks to mid-crustal levels are preserved. Ultrapotassic rocks (durbachites) of the Strážek Unit, dated at $\sim 339 \mathrm{Ma}$, intruded posttectonicaly.

Keywords: Central European Variscides, Bohemian Massif, Moldanubian Zone, West Sudetes, metamorphic structures, calc-alkaline plutons

Received: 11 March 2009; accepted 15 June 2009; handling editor: V. Kachlik

\section{Introduction}

The present paper outlines the geological and tectonic setting of the units extending along the northern margin of the Moldanubian Zone (Figs 1-2) from the Strážek Unit in the south through the Kutná Hora Complex, Svratka, Polička and Zábřeh units up to the southern part of the Orlice-Sněžník Unit in the NE.

The Strážek Unit, as a part of the Moldanubian Zone, corresponds to exhumed high-grade, lower- to mid-crustal rocks that recorded a polyphase Variscan tectonometamorphic record (for a general review, see Urban and Synek 1995; Vrána et al. 1995). The Kutná Hora Complex and the Svratka Unit represent a crustal stack of rocks with different lower- to mid-crustal history (e. g. Synek and Oliveriová 1993; Melichar ed. 2008).

The structurally uppermost Polička and Zábřeh units are composed of less metamorphosed volcanosedimentary sequences, probably with the broad affinity to the TepláBarrandian Unit (Bohemicum). The Orlice-Sněžník Unit as part of the West Sudetes (Lugicum) consists of highgrade polymetamorphic migmatites, orthogneisses and metasediments. The protoliths to orthogneisses was dated as Cambro-Ordovician (Kröner et al. 2001), metasediments are probably of Neoproterozoic to Early Palaeozoic age. The HP rocks including granulites, eclogites and peridotites reveal both Palaeovariscan and Neovariscan crystallization/equilibration ages.

In general, the geological evolution of some rocks in the studied area started during Neoproterozoic to earliest Palaeozoic times ( $\sim 570-530 \mathrm{Ma})$. Late Cadomian subduction at the northern periphery of the Gondwana continent was followed by crustal extension and incipient rifting (e.g. Franke 2000; Hegner and Kröner 2000; Kröner et al. 2000a). The Cambro-Ordovician rifting event led to the opening of the Rheic Ocean (for a general review, see Kröner et al. 2000a; Linnemann et al. 2008). The Variscan orogeny was initiated by the Devonian to Early Carboniferous collision of Gondwana-derived crustal segments with the Old Red (Laurussia) continent (see Franke 2000 for an overview). Palaeovariscan orogenic processes, supported by ages near $380-370 \mathrm{Ma}$, are poorly constrained at present due to an extensive Neovariscan overprint (Mazur et al 2006). The subsequent continental subduction, succeeding in consumption of oceanic domains and accompanied by HP/HT metamorphism at $\sim 340 \mathrm{Ma}$, was 


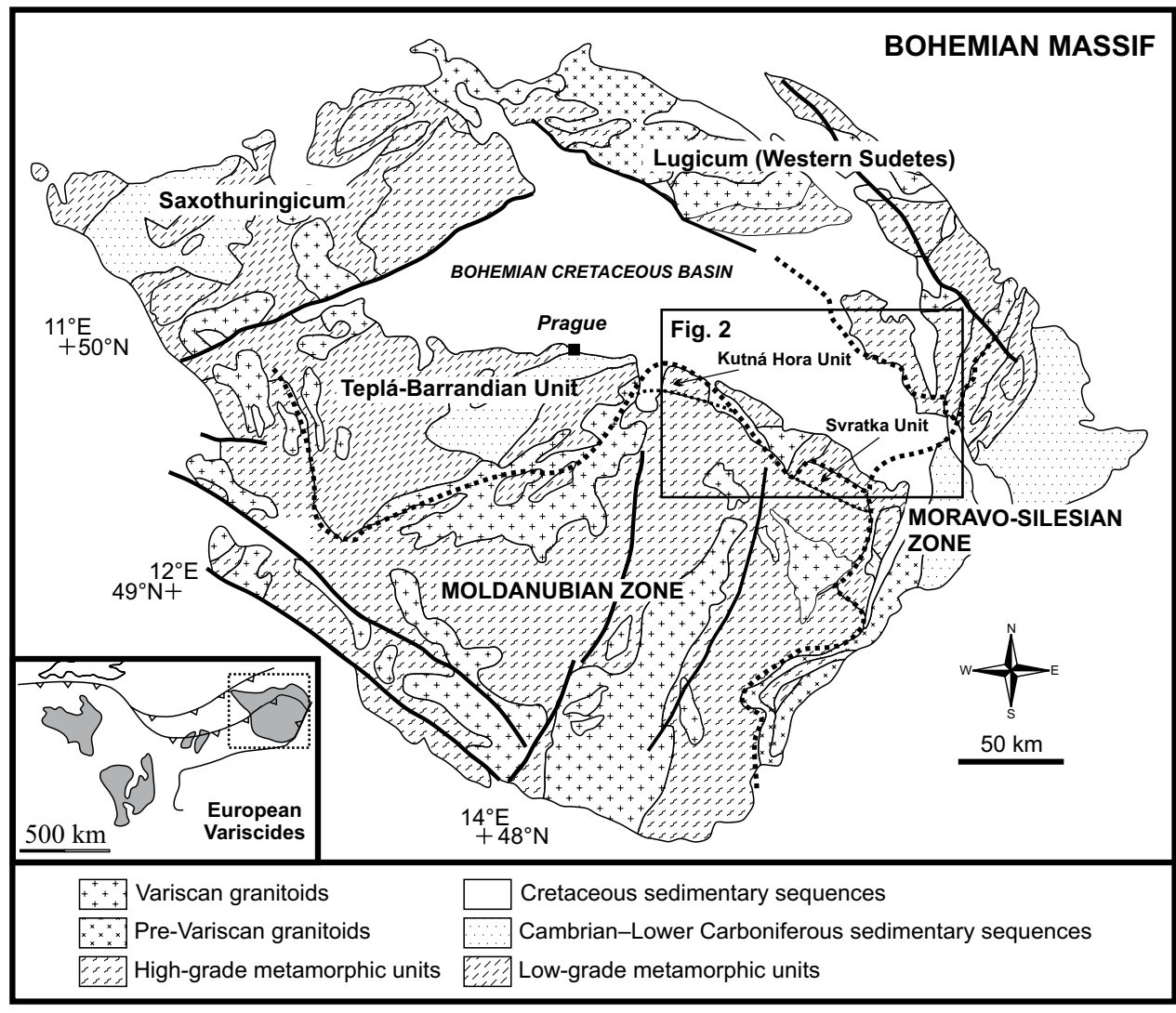

Fig. 1 Geological sketch map of the Bohemian Massif with location of the study area at the NE periphery of the Moldanubian Zone. After Franke et al. (2000). (e.g., Drost et al. 2004; Dörr and Zulauf in print); (iii) Lugicum (West Sudetes) and Saxothuringicum including Neoproterozoic to Lower Palaeozoic basement rocks with tectonically implanted slices of the Variscan HP and UHP rocks (Kröner et al. 2001; Mazur et al. 2005, 2006). The eastern margins of the Moldanubian and Lugian domains were thrust over the Moravo-Silesian Zone nape pile (Schulmann et al. 1991; Schulmann and Gayer 2000). The Moravo-Silesian Zone consists of a pre-Variscan, mostly metaigneous basement with deformed and a tectonically-imbricated metasedimentary sequence of Devonian age (for a review, see Finger et al. 2000; Schulmann and Gayer 2000). followed by isostatically-driven, very fast exhumation of deep-seated rocks (Kröner et al. 2008; Schulmann et al. 2009 and references therein).

The orogenic processes were accompanied by extensive magmatic/plutonic activity (Finger et al. 1997). In the studied area two main stages of Variscan magmatic activity were identified (Buriánek et al. 2003; Janoušek and Holub 2007): (i) The calc-alkaline plutons (dated at $\sim 350 \mathrm{Ma}$ ) intruded the Polička and Zábřeh units; (ii) emplacement of the ultrapotassic (durbachite) plutons ( 343-335 Ma) in the Moldanubian Zone. The Kutná Hora Complex and the Svratka Unit are devoid of Variscan plutons.

The accretion of individual blocks/units of the Central European Variscides (Bohemian Massif) led to the juxtaposition of different crustal segments (e.g. Schulmann et al. 2009): (i) the Moldanubian Zone (MZ) built by Variscan and pre-Variscan lower- to mid-crustal rocks (for a general review see e.g. Fiala at al. 1995; Urban and Synek 1995; Schulmann et al. 2008); (ii) the TepláBarrandian Unit (TBU) representing the upper-crustal segment composed of Neoproterozoic rocks metamorphosed during the Cadomian event overlain by deformed volcanosedimentary sequence of Lower Palaeozoic age

\section{Regional geological setting and structural pattern}

\subsection{North-eastern part of the Moldanubian Zone}

The Moldanubian Zone (MZ) is a super-unit representing a heterogeneous crustal stack of units and rock types with contrasting lithology, ages and tectonometamorphic evolution. The Monotonous Unit contains a uniform sequence dominated by partly migmatitized paragneisses. The Varied Unit is built by paragneisses with abundant intercalations of marbles, calc-silicate rocks, quartzites, graphitic gneisses and amphibolites. Varied unit had sedimentary protoliths mainly of Early Palaeozoic age (Fiala et al. 1995, Drábek and Stein 2003; Janoušek et al. 2008). The Gföhl Unit is composed of lower-crustal and upper mantle components (granulites, migmatitic orthogneisses, with lenses of peridotites and eclogites) derived from heterogeneous sources. The SHRIMP U-Pb dating on zircons indicates a protolith age of $488 \pm 6 \mathrm{Ma}$ for Gföhl migmatitic orthogneisses (Friedl et al. 2004). These orthogneisses 


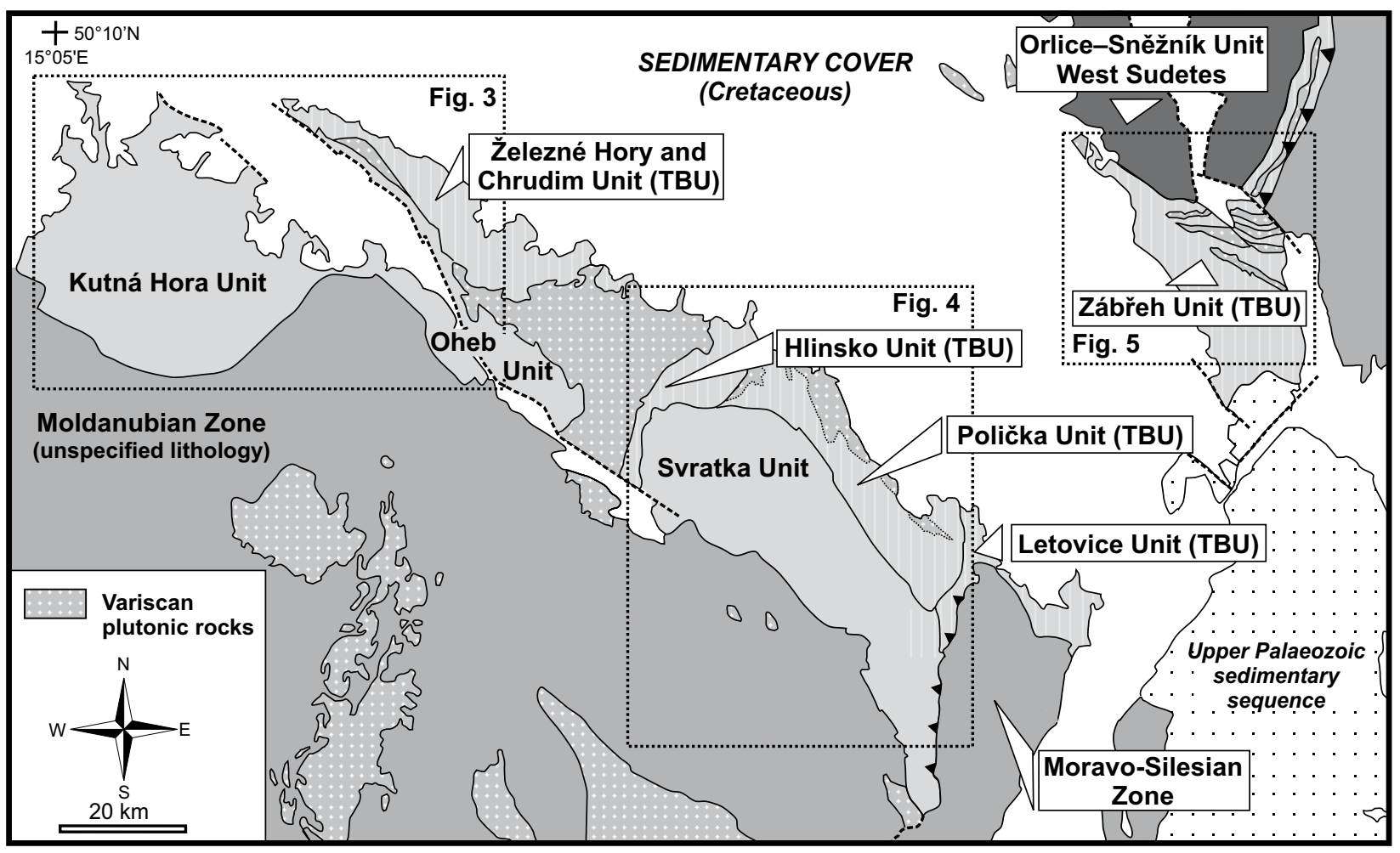

Fig. 2 Simplified geological map of the NE periphery of the Moldanubian Zone showing the positions of detailed structural maps (Figs 3-5). After Cháb et al. (2007).

with Mesoproterozoic and Palaeoproterozoic ages were incorporated in the southern Moldanubian Zone (i.e., Dobra orthogneisses of $\sim 1.38 \mathrm{Ga}$ and Světlík orthogneisses of $\sim 2.08$ Ga protolith ages, Wendt et al. 1993; Friedl et al. 2004).

In general, the estimated P-T conditions of regional metamorphism in rocks of the Monotonous and Varied units fall in the wide range of $\mathrm{T}=630-720^{\circ} \mathrm{C}$ and $\mathrm{P}=$ 0.4-1.0 GPa (Vrána et al. 1995; Linner 1996; Racek et al. 2006). The P-T conditions of peak metamorphism of granulites and eclogites in the Gföhl Unit were calculated at $\mathrm{T}=\sim 850-1000^{\circ} \mathrm{C}$ and $\mathrm{P}=\sim 1.5-2.0 \mathrm{GPa}$, with subsequent retrograde metamorphism at $\mathrm{T}=\sim 600-800^{\circ} \mathrm{C}$ and $\mathrm{P}=\sim 0.6-0.8 \mathrm{GPa}$ (for review see Štípská et al. 2004; Tajčmanová et al. 2006).

Given the geodynamic evolution outlined above the structural record of the Moldanubian Zone is complicated and several regional fabrics are observed. On the basis of several petrostructural studies new concepts of tectonic evolution were published. For example, one of the early fabrics are steeply dipping $\sim \mathrm{NNE}-\mathrm{SSW}$ metamorphic foliations, preserved in relicts across the MZ, interpreted by some authors as having originated due to vertical extrusion of lower-crustal rocks (e.g. Tajčmanová et al. 2006). In addition, the Variscan exhumation processes were associated with formation of well-developed, mod- erately-dipping to "flat-lying" orogenic fabrics. The interpretations of Moldanubian flat-lying fabrics are in part controversial (see Verner et al. 2008 for discussion).

The northeastern part of the Moldanubian Zone (designated as the Strážek Unit) is composed of migmatized paragneisses with calc-silicate intercalations and migmatites with a amphibolite layers (Medaris et al. 1995; Owen and Dostal 1996; Hanžl ed. 2008). Felsic granulites and ultramafic rocks derived from upper mantle (Weiss 1992) are interpreted as allochthonous bodies. Metamorphic evolution in the Strážek Unit is similar to the metamorphic record in other parts of the Moldanubian Zone. High-temperature and high-pressure conditions identified in granulites, eclogites and garnet peridotites were followed by the nearly isothermal decompression at high temperatures (Medaris et al. 1995; Owen and Dostal 1996; Tajčmanová et al. 2006). The structural pattern of the Strážek Unit is defined by three superimposed regional metamorphic foliations with associated mineral lineations: (i) earlier, steeply dipping foliation with regional $\sim$ NNE-SSW strike is heterogeneously reworked into (ii) flat-lying fabric occurring in the central part of the Strážek Unit and (iii) gently to moderately $\sim \mathrm{NE}$ or $\sim \mathrm{SW}$ dipping metamorphic foliation, defining the northern boundary of the Moldanubian Zone, bearing a NW-SE trending mineral lineation (Fig. $6 \mathrm{c}$ ). The 
above structures are truncated in some places by intrusive contacts of the ultrapotassic (durbachite) intrusions dated at $\sim 323 \mathrm{Ma}$ (Schulmann et al. 2005) or $\sim 339 \mathrm{Ma}$ (unpublished geochronological data of A. Gerdes). Given the ages for other ultrapotassic bodies in the Moldanubian Zone falling into a relatively short interval of $\sim 343-335$ Ma (Janoušek and Holub 2007 for review), the latter age datum is considered more likely.

\subsection{Kutná Hora Complex (KHC)}

The Kutná Hora Complex (western part of the Kutná Hora-Svratka Super-unit; Fig. 2) consists of three different structural and lithological parts (Synek and Oliveriová 1993; Kachlík 1999) including the Malín Plaňany and Běstvina units, which are overlying the Kouřim and Mica Schist units (Figs 2-3).

The three uppermost units represent volcanosedimentary sequences of unidentified stratigraphy and poorly known metamorphic age. The Běstvina Unit (defined by Losert 1967) is formed by felsic granulites and migmatized gneisses with lenses of garnet peridotites, eclogites and rare garnet amphibolites. The Malín Unit (Losert 1956a, b) consists mainly of kyanite-bearing migmatites accompanied by garnet amphibolites, partly serpentinized garnet peridotites/lherzolites, eclogites and several skarn bodies. The Plaňany Unit (Fišera 1977) is represented by various types of migmatites with lenses of amphibolites, serpentinites and pyroxenites.

The underlying part of the Kutná Hora Complex is represented by the Kourim Unit (termed also the Kouřim Orthogneiss Nappe), consisting of granitic orthogneisses and fine-grained leucocratic migmatites. The lowermost Mica Schist Unit represents a sequence of metapelites intercalated with amphibolites and marbles (Synek and Oliveriová 1993; Kachlík 1999). The structural analysis by Synek and Oliveriová (1993) documented a polyphase history including three major tectonometamorphic events. These authors suggested that the thrusting of the three allochthonous units took place after most of their tectonometamorphic evolution was completed. At first, the bodies of HP-HT granulites, eclogites and garnet peridotites/lherzolites were emplaced in the Běstvina and Malín units during the initial $\sim$ HT-HP tectonometamorphic event. In addition, the felsic granulites of the Běstvina Unit were equilibrated under eclogite-facies conditions ( $\mathrm{P}=\sim 1.8-2.1 \mathrm{GPa}$; Vrána et al. 2005). The early structures are generally rare, corresponding foliation planes dip steeply to the $\sim \mathrm{NE}$.

The following tectonometamorphic event was connected with intense migmatization producing kyanite-bearing

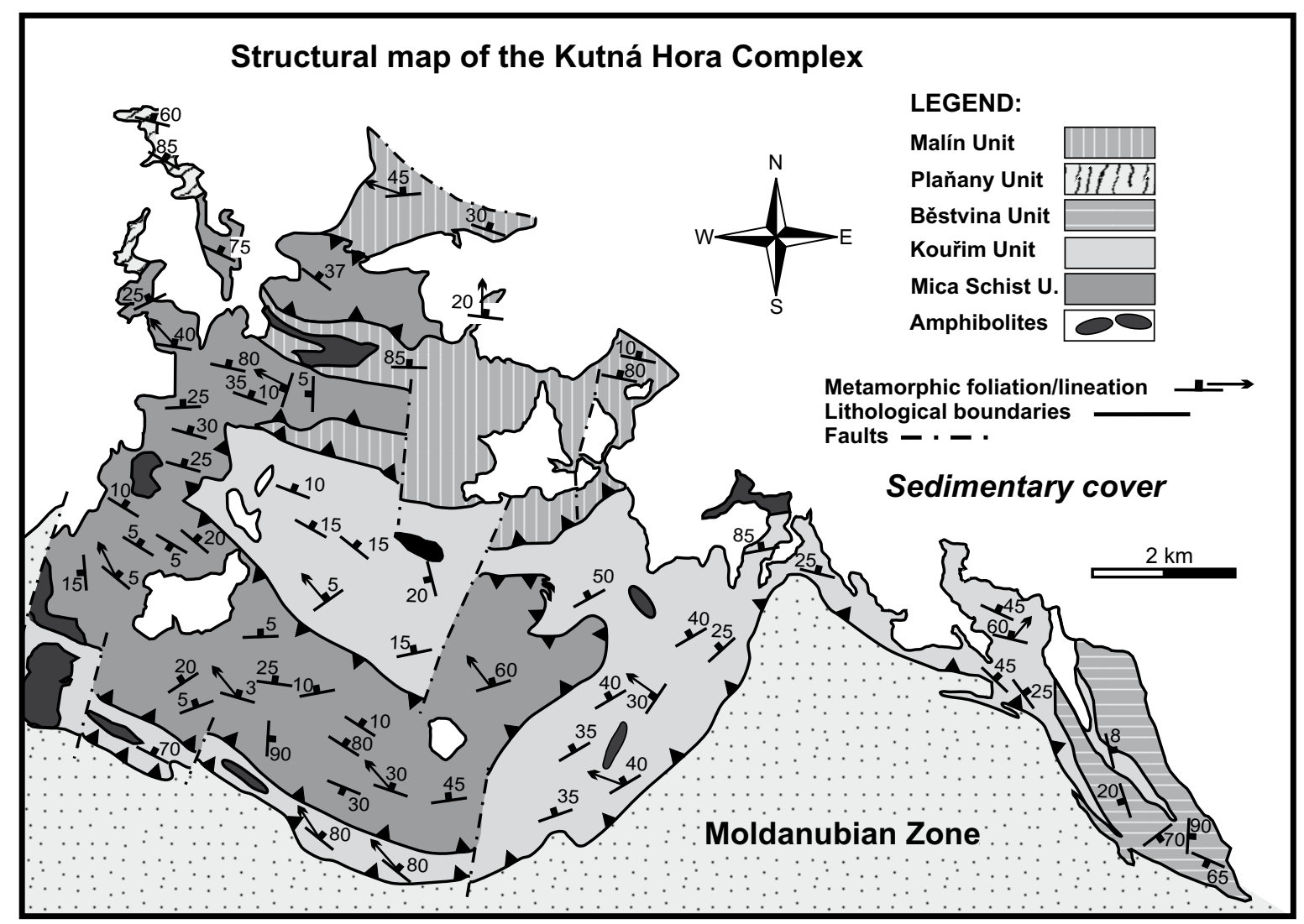

Fig. 3 Structural and geological sketch of the Kutná Hora Unit. After Synek and Oliveriová (1993). 
leucosomes $(\mathrm{P}=1.5 \mathrm{GPa})$. The last event was characterized by superimposed retrograde metamorphism under HP amphibolite-facies conditions (formation of foliation with newly crystallized biotite, muscovite \pm garnet and kyanite: Vrána et al. this volume).

The structurally uppermost units of the Kutná Hora Complex represent segments of high-pressure, deeper parts of the Palaeovariscan crust, which were not affected by late LP-HT Variscan metamorphic overprint.

\subsection{The Svratka Unit}

The Svratka Unit (SU), located in the eastern part of the Kutná Hora-Svratka Superunit has a $\sim \mathrm{NW}-\mathrm{SE}$ elongated shape with brachyanticlinally-terminated NW part (Fig. 2). The longest dimension is $\sim 35 \mathrm{~km}$ and the shortest is 1 to $15 \mathrm{~km}$. The Svratka Unit consists of polymetamorphic migmatites, paragneisses and mica schists, with elongated bodies of Cambro-Ordovician metagranites to orthogneisses. Minor lithologies are represented by layers of dolomitic marbles, calc-silicate rocks, amphibolites and skarns (Němec 1998; Melichar ed. 2008; Hanžl ed. 2008). The Svratka metagranites recently dated at 515 $\pm 9 \mathrm{Ma}$ (U-Pb zircon, Schulmann et al. 2005) were emplaced during the Cambro-Ordovician magmatic event into the older migmatitized rocks. The maximum age of the volcanosedimentary complex is defined by abundant detrital zircons in strata-bound skarns dated at $~ 540-600$ Ma (Pertoldová et al. this volume).

During the Variscan Orogeny, the whole Svratka Unit was affected by penetrative deformation and regional metamorphism, which attained amphibolite-facies conditions $\left(\mathrm{T}=\sim 640-670{ }^{\circ} \mathrm{C}\right.$ and $\mathrm{P}=\sim 0.7-0.8 \mathrm{GPa}$; Pitra and Guiraud 1996; D. Buriánek unpublished data). Subsequently, these rocks were subject to a partial decrease in pressure of about $\sim 0.2 \mathrm{GPa}$ and crystallization of new mineral assemblage $(\mathrm{Ms}+\mathrm{Bt}+\mathrm{Grt}+\mathrm{St} \pm \mathrm{Sill})$ corresponding to $\mathrm{T}=580-650{ }^{\circ} \mathrm{C}$ and $\mathrm{P}=\sim 0.6 \mathrm{GPa}$ (D. Buriánek unpublished data). In the case of skarns, the relicts of the oldest $\sim \mathrm{HP}$ metamorphism (c. $\sim 1.4 \mathrm{GPa}$ ) were identified (Pertoldová 1986; Pertoldová et al. this volume).

The regional structures are defined by penetrative metamorphic foliation associated with well-developed stretching lineation. This foliation (compositional and deformational layering) dips in the western and central parts of the Svratka Unit under moderate angles to the $\sim \mathrm{NNW}-\mathrm{NE}$, whereas in the eastern domain dips steeply to moderately to the $\sim \mathrm{SW}$. The well-developed metamorphic lineation (elongated quartz and feldspar aggregates, lattice preferred orientation of new micas) has a relatively uniform geometry in the whole unit and dips under low angles to the $\sim \mathrm{NW}$ or SE. The orientation of the penetrative metamorphic structures described above defines well the regional structural framework of the NE periphery of the Moldanubian Zone. Rarely there were encountered relicts of older metamorphic fabric (of an unknown age) in the form of rootless isoclinal folds (Fig. 6b), especially in quartzo-feldspathic rocks, enclosed within the $\sim \mathrm{NW}-$ SE trending regional fabric. In less deformed parts, especially in metagranite and polymetamorphic migmatite bodies, relicts of magmatic or migmatite textures (e.g. relict magmatic zoning in minerals and incipient stage of recrystallization in metagranites, evidence for primary crystallization textures of leucosomes in migmatites) can be observed. The effect of the Variscan deformation and recrystallization include dynamically recrystallized quartz and feldspar aggregates accompanied by a subsolidus deformation of primary grains (Zavřelová et al. 2006; Buriánek et al. this volume). On the other hand, the pervasive fabric of the SU is locally modified by brittleductile and brittle extensional deformation (e. g., in the form of narrow shear zones and faults, or extensional kink-band folds).

\subsection{Eastern part of Teplá-Barrandian Unit (TBU)}

The TBU is an independent upper-crustal segment positioned between the Saxothuringian Zone and exhumed Moldanubian Zone. In general, the Teplá-Barrandian Unit is subdivided into a metamorphosed basement of Neoproterozoic (Cadomian) age, transgressively overlain by Cambrian to Middle Devonian volcanosedimentary sequence of deformed but unmetamorphosed rocks (e.g. Chaloupský et al. 1995; Melichar 2004). The Polička and Zábřeh units are interpreted by some geologists as the easternmost equivalents of the Teplá-Barrandian Unit (see Mísař and Dudek 1993). The Polička and Zábřeh units were affected by a variable degree of Variscan tectonometamorphic overprint under greenschist- and amphibolite-facies conditions. The pre-Variscan structures in these units were extensively obliterated (Pitra et al 1994; Buriánek et al. 2003).

\subsubsection{Polička Unit (PU)}

As seen in Fig. 4, the PU is separated from the overlying, less metamorphosed metasediments of the Hlinsko Unit (possibly corresponding to the TBU - Vachtl 1962; Pitra and Guiraud 1996) by localized, NNE-SSW trending, normal low-temperature shear zones and faults (Fig. 6d). The protolith to the rocks of the Polička Unit corresponded to a relatively monotonous Neoproterozoic and Lower Palaeozoic sequence of flysch sediments and volcanic rocks (Kodym and Svoboda 1950). During the Variscan orogenic processes, the volcanosedimentary sequence of the PU was affected by regional metamorphism 
under lower amphibolite-facies conditions, accompanied by emplacement of calc-alkaline (granodiorite to tonalite) intrusions, Budislav and Miřetín plutons. On the basis of its lithological composition, the PU was subdivided by Melichar (1995) into three main parts: (i) mediumgrained biotite and two-mica gneisses with amphibolites, marbles and associated calc-silicate rocks present along the boundary with the overlying Svratka Unit; bodies of leucocratic metagranites are present in the southern part of Polička Unit, (ii) the central part of the Polička Unit, consisting of a monotonous sequence of mediumgrained paragneisses with calc-silicate nodules (up to $0.5 \mathrm{~m}$ thick), and (iii) the northern part, composed of paragneisses with lenses of mica schists and quartzites and abundant calc-alkaline granitic rocks. The Variscan metamorphic evolution across the Polička Unit shows a slight variation. Relicts of the prograde $\sim \mathrm{LP}-\mathrm{MT}$ metamorphism $\left(\mathrm{T}=560{ }^{\circ} \mathrm{C}\right.$ and $\left.\mathrm{P}=0.3 \mathrm{GPa}\right)$ are preserved only in its western part; the metamorphic grade increases from the west to the east, with a maximum at $\mathrm{T}=\sim 580$ $680^{\circ} \mathrm{C}$ and $\mathrm{P}=\sim 0.5-0.7 \mathrm{GPa}$. The advective heat input related to granitic intrusions, is at present poorly defined. Finally, retrograde metamorphism took place that was manifested by aggregates of newly formed muscovite (Buriánek et al. 2003).

In the southeast, the Polička Unit is rimmed by a segment of Variscan felsic granulites and associated orthogneisses, (designated Vír Area) The Vír granulites reached peak temperatures of $\sim 850-900{ }^{\circ} \mathrm{C}$ and pressures of $1.3-$ $1.4 \mathrm{GPa}$ (Tajčmanová et al. 2006), followed by retrograde metamorphic overprint under amphibolite-facies conditions $\left(\mathrm{T}=\sim 600^{\circ} \mathrm{C}\right.$ and $\mathrm{P}=0.6-0.8 \mathrm{GPa}$, Štoudová et al. 1999). The metamorphic evolution including an early high HP/HT stage, followed by HT decompression, resembles granulites in the Moldanubian Zone (see above).

The overall structural pattern of the Polička Unit (Fig. 4) is defined by regional metamorphic foliation (pervasive schistosity or compositional banding), which dips moderately to the $\sim \mathrm{NE}$ in its central and eastern parts. Foliations steeply to moderately dipping to the $\sim$ WNW were mapped in the western part of the Polička Unit. Well-developed, gently $\sim \mathrm{NW}-\mathrm{SE}$ plunging stretching lineation, bearing indicators of dextral kinematics, was observed across the Polička Unit.

The northern part of PU was intruded by numerous igneous bodies of calc-alkaline composition (i.e. the Miřetín and Budislav plutons; Buriánek et al. 2003; Vondrovic and Verner 2008). The Budislav Pluton was emplaced within the northern part of the Polička Unit (dated at $350 \pm 5 \mathrm{Ma}$; $\mathrm{U}-\mathrm{Pb}$ method on zircon; Vondrovic and Verner 2008). In the Budislav Pluton, magmatic to HT sub-solidus fabrics defined by shape-preferred orientation of plagioclase, amphibole and biotite aggregates were identified. The corresponding foliations dip under moderate angles to the $\sim \mathrm{NE} / \mathrm{SW}$ and the associated strongly-developed lineations have a sub-horizontal orientation. The overall fabrics in the Budislav Pluton are roughly parallel to the pluton intrusive contacts, as well as to the orientation of the regional metamorphic fabric in the Polička Unit.

The second intrusive body of the PU, the Miřetín Pluton, is deformed medium-grained, porphyritic biotite tonalite to granodiorite that intruded the western flank of the Polička Unit, at the border with the Hlinsko and Svratka units. The crystallization age of the Miřetín Pluton was determined at $348 \pm 7 \mathrm{Ma}$ (U-Pb zircon; Vondrovic and Verner 2008). The Miřetín Pluton has a $\sim$ NNE-SSW elongated shape (Fig. 4). Two distinct solidstate fabrics were recognized in this pluton. (i) Relatively older, pervasive high-temperature solid-state foliation dips under moderate angles to the $\sim \mathrm{WNW}$. These foliation planes are accompanied by well developed stretching lineations plunging to the $\sim \mathrm{NW}$ and overthrusting kinematic indicators. (ii) Along the western rim of the Miřetín Pluton, the low-temperature cleavage, roughly parallel to the boundary between the Polička and Hlinsko units, was superimposed on the older fabrics (Fig. 6d).

\subsubsection{Zábřeh Unit (ZU)}

The Zábřreh Unit is adjacent to the Lugicum (West Sudetes; for a general review see Franke and Żelaźniewicz 2000; Mazur et al. 2006). It is positioned in the hanging wall of the exhumed pre-Variscan and Palaeovariscan deep-crustal rocks of the Orlice-Sněžník Unit (OSU). The Zábřeh Unit is a volcanosedimentary complex, originally classified as a part of the Lugicum (Mísař and Dudek 1993). In lithological composition it rather corresponds to the Polička and Hlinsko units (i.e., the eastern prolongation of the Teplá-Barrandian Unit; Mísař and Dudek 1993; Buriánek et al. 2003). In detail, the Zábřeh Unit is composed of two lithological parts (Fajst 1976; Hanžl et al. 2000; Buriánek et al. 2003). The southern part is formed by low-grade metapelites and metabasites, while the northern includes paragneisses with intercalations of amphibolites and acid metavolcanites (Fig. 5). The intensity of the Variscan metamorphism increases from the central part to the south and north. The P-T conditions estimated from the northern part of the Zábřeh Unit fall in the middle of the amphibolite-facies field ( $P \sim 0.6 \mathrm{GPa}$ and $\mathrm{T} \sim 660^{\circ} \mathrm{C}$; D. Buriánek unpublished data). Rocks of the northern segment of the Zábřeh Unit were intruded by numerous sills and dykes of calc-alkaline rocks of broadly granodioritic composition (called the Zábřeh Intrusive Complex). Geochemical similarities between the calc-alkaline rocks from the Zábřeh and Polička units were demonstrated by Buriánek et al. (2003). The crystallization age of the former intrusive rocks was estimated 


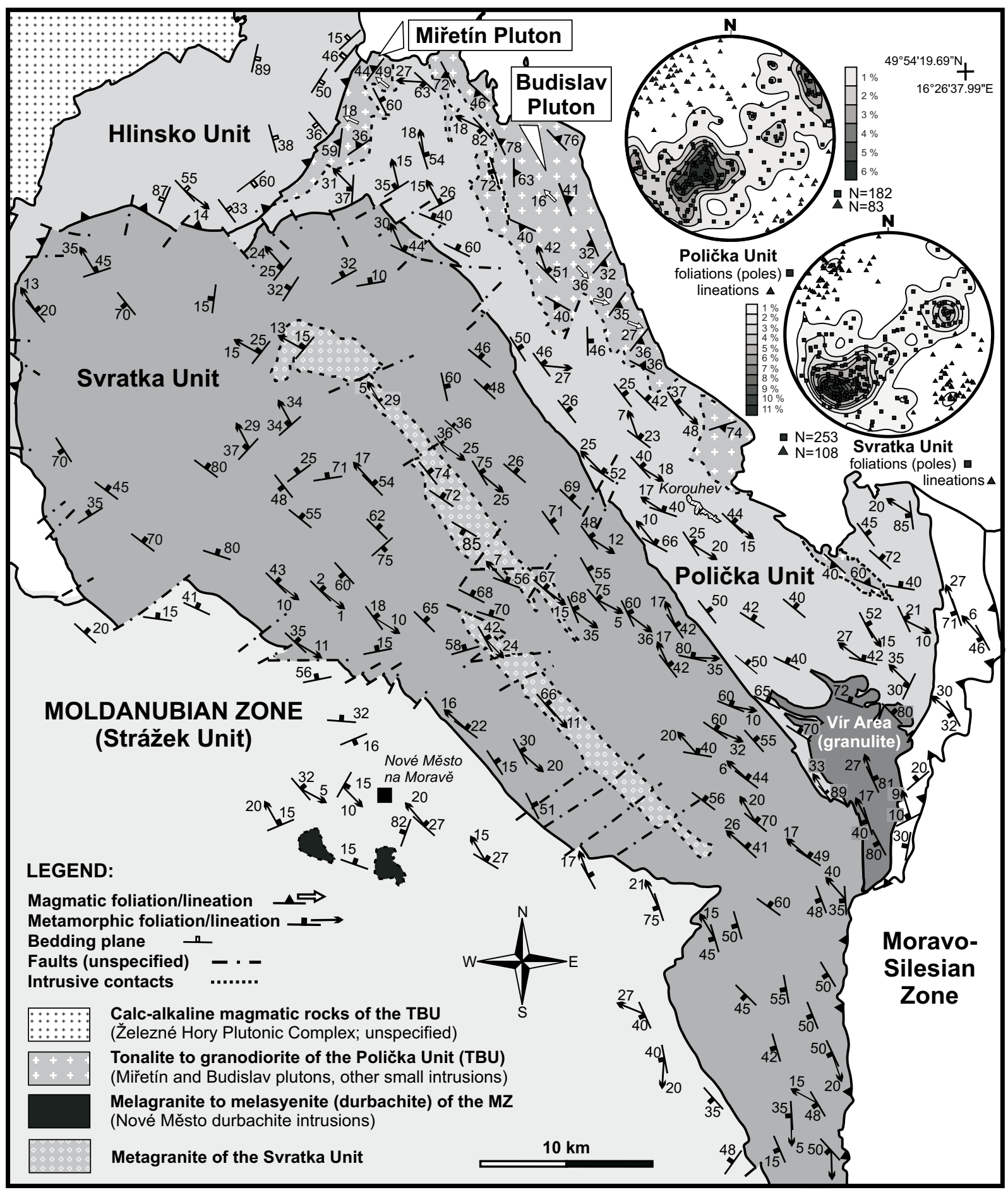

Fig. 4 a - Structural and geological sketch of the mid- to upper-crustal Svratka and Polička units including the neighbouring metamorphic complexes. b - Stereograms (lower hemisphere, equal area projection) of foliations and lineations from the two main units. Modified after Cháb et al. (2007), Hanžl ed. (2008), Melichar ed. (2008).

by the U-Pb method on zircon at $\sim 354 \mathrm{Ma}(\mathrm{V}$. Kachlík and J. Sláma unpublished data). Some effects of contact metamorphism and local partial melting (anatexis) were observed in narrow zones along these intrusions.
Two distinct metamorphic fabrics occur in the structural framework of the Zábřeh Unit. The dominant metamorphic foliation generally dips under moderate angles to the $\sim \mathrm{SSW}$ (see the maxima in stereograms and 
structural map; Fig. 5) and is associated with well-developed mineral and stretching lineation gently plunging to the $\sim$ SE. In the northern part of the Zábřeh Unit, folded relicts of planar structures with steeply dipping E-W orientation were observed. Locally, towards the southern part of the Zábřeh Unit, the regional metamorphic foliation was deformed into large open folds with $\sim \mathrm{E}-\mathrm{W}$ oriented axes. The orientation of intrusive contacts and fabrics (magmatic to sub-solidus foliation and well-developed lineation) of the granodiorite intrusions of the Zábřeh Intrusive Complex are roughly parallel to the orientation of the younger regional metamorphic fabric. The boundary between the less metamorphosed rocks of the Zábřeh Unit and the adjacent underlying lower to mid- crustal Orlice-Sněžník Unit (Lugicum) is roughly parallel to the regional metamorphic fabric in the northern part of the Zábřeh Unit. In the southern part of the Orlice-Sněžník Unit, these margin-parallel foliations are superimposed on "flat-lying" fabrics (Fig. 5).

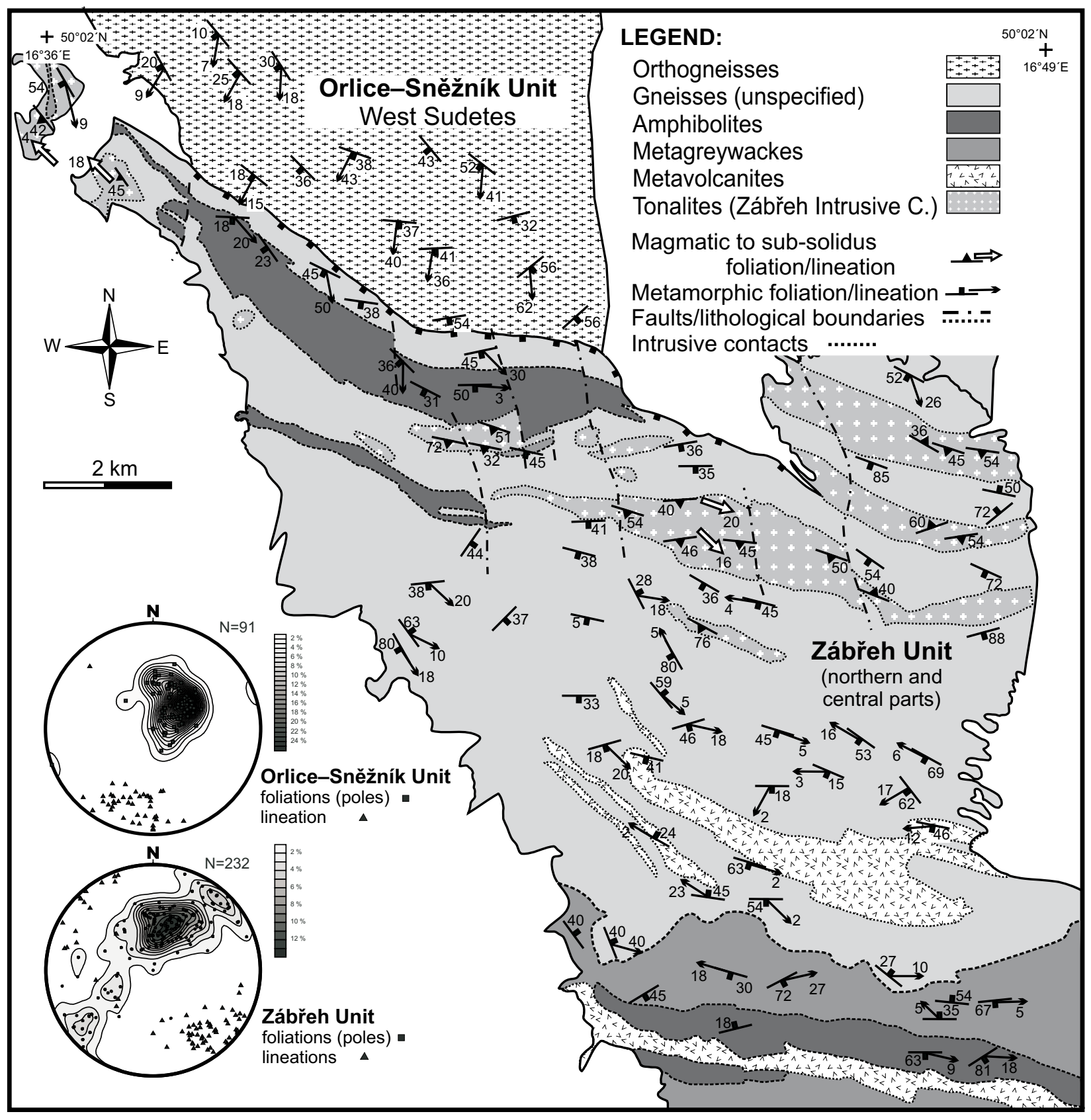

Fig. 5 a - Structural and geological sketch of the Zábřeh Unit and southern part of the Orlice-Sněžník Unit. b - Stereograms (lower hemisphere, equal area projection) of foliations and lineations from the both units. Modified after Cháb et al. (2007). 


\subsection{Orlice-Sněžník Unit (OSU)}

The OSU occurs in the SE part of the Lugicum (West Sudetes). It consists of high-grade polymetamorphic migmatites, orthogneisses (both originally of Cambro-Ordovician age; Kröner et al. 2001; Bröcker et al. 2009) and schists with inclusions of HP and UHP rocks (eclogites and granulites). For a general review of the lithological composition and geochronology of the Orlice-Sněžník Unit, see Kröner et al. (2001). Rocks of the OSU show high- to medium- grade Variscan tectonometamorphic overprint recorded in several principal phases: (i) the first reflects prograde UHP metamorphic conditions in granulites at around $386 \mathrm{Ma}$ (Anczkiewicz et al. 2007); (ii) the second event ( $\sim 340 \mathrm{Ma})$ was associated with the HT retrograde metamorphism of the lower-crustal rocks (Kryza et al. 1996; Anczkiewicz et al. 2007) and (iii) additional retrograde processes under the amphibolite-facies conditions (Jastrzębski in print).

Compared to the complex metamorphic history of the Orlice-Sněžník Unit, some additional fabrics were described (Fajst 1976; Cymerman et al. 1997). The structural pattern in the southern part of the OSU is dominated by "flat-lying" retrograde mylonitic foliation associated with well-developed $\sim \mathrm{N}-\mathrm{S}$ lineation.

\section{Discussion}

The units at the NE periphery of the Moldanubian Zone carry a set of structures and metamorphic fabrics reflecting the Variscan geodynamic evolution in a regional cross-section, from the high-grade rocks of the Moldanubian Zone to the mid- and upper-crustal segments of the Svratka Unit as well as the Polička and Zábřeh units. In the northeast, high-grade rocks reappear in the Orlice-Sněžník Unit. With regard to some similarities in lithology and Variscan tectonometamorphic evolution of the Polička and Zábřeh units (e.g., Buriánek et al. 2003; Buriánek et al. this volume), they can be perhaps correlated with some less metamorphosed segments of the Teplá-Barrandian Unit (e.g., the Hlinsko Unit).

The high-grade rocks of the Vír Area (Vír granulite; for specification see Tajčmanová et al. 2006), conventionally classified as the SE part of the Polička Unit, were probably derived from the Moldanubian lower crust and incorporated tectonically in their present position. The Vír segment should be considered as a separate crustal slice independent of the Polička Unit.

In the case of the Kutná Hora Complex, there are substantial differences in the lithology and Variscan tectonometamorphic evolution between the structurally uppermost members of the KHC (Malín, Běstvina and Plaňany units) and the Svratka Unit. The stratigraphic age of the three allochtonous units in the KHC is unknown but their HP/HT metamorphism is probably of Palaeovariscan age as indicated by $\mathrm{Sm}-\mathrm{Nd}$ dating of garnet peridotites and pyroxenites from the Malín Unit ( $\sim 378 \mathrm{Ma}$; Brueckner et al. 1996). On the other hand, the structurally lower Kouřim and Mica Schist units could be probably correlated with similar lithologies in the Svratka Unit. At present, there is not sufficient information permitting classification of the individual structural patterns that were defined in the Kutná Hora Unit by Synek and Oliveriová (1993) as belonging to Palaeovariscan or Neovariscan deformation events.

The structures of pre-Variscan age are rarely preserved in the complex of polymetamorphic migmatites of the Svratka Unit (Fig. 6a). Angular blocks of leucocratic migmatites with well-developed, leucosome textures are enclosed in Cambro-Ordovician metagranites as xenoliths. The Svratka metagranites were emplaced at $\sim 515$ Ma (Schulmann et al. 2005). The emplacement of the Svratka metagranite took place most likely during crustal extension, close to early Cambro-Ordovician geodynamic processes (Hegner and Kröner 2000; Kröner et al. 2000a; Buriánek et al. this volume).

In addition, the deformation-resistant skarn bodies retain some relicts of older deformation structures and keep record of the pre-Variscan prograde metamorphic evolution, with mineral assemblages indicating conditions of $\sim 1.4 \mathrm{GPa}$ (Pertoldová et al. this volume).

During the Variscan orogeny, two principal metamorphic fabrics were formed in the studied area. The relatively older fabrics occur in a distant part of the Moldanubian Zone (i.e. in the centre of the Strážek Unit). Some authors interpreted these steep N-E trending foliations as the earliest structures in the Strážek Unit to be associated with early stages of the Moldanubian Zone exhumation (Štípská et al. 2004; Tajčmanová et al. 2006; Schulmann et al. 2008). The relatively younger regional fabrics in the Strážek Unit were imprinted under amphibolite-facies conditions $\left(\mathrm{T} \sim 620^{\circ} \mathrm{C}\right.$ and $\mathrm{P} \sim 0.5 \mathrm{GPa}$; Tajčmanová et al. 2006). In the Svratka and Polička units similar fabrics bear characteristics of penetrative deformation under peak metamorphic conditions. In general, this relatively younger mid- to upper-crustal pervasive metamorphic schistosity dips moderately to the $\sim \mathrm{NNE}-\mathrm{NE}$ or to the $\sim \mathrm{SSW}-\mathrm{SW}$ in the southeastern part of the studied area. These planar fabrics are generally associated with well-developed, subhorizontal stretching lineation and right-lateral kinematic indicators (indicating transpressional to transtensional tectonics). The ages for HP/HT equilibration of Moldanubian granulites, garnet peridotites and associated ultramafic rocks falling into the narrow range of 340-338 Ma (Becker 1997; Kröner et al 2000b; Tajčmanová et al. 2006) and crystallization ages of ultrapotassic intrusions ( $\sim 339$ Ma; Janoušek and Holub 2007) prove that the ex- 
humation of the Moldanubian Zone closely followed this HP/HT event. This means that deformation structures and mineral assemblages in micaceous gneisses at the contact of the Moldanubian Zone with the Svratka Unit and Kutná Hora Complex must have post-dated the exhumation of the Moldanubian Zone.

During the Variscan evolution, the $\sim 350$ Ma old calcalkaline igneous magmas (Budislav Pluton and the Zábřeh Intrusive Complex) were emplaced in the eastern part of the Polička and the Zábřeh units (Vondrovic and Verner 2008). In both plutons, relicts of magmatic fabric were overprinted by regional $\sim$ WNW-ESE magmatic to HT solid-state foliation associated with subhorizontal lineation. These relationships indicate that calc-alkaline intrusions bear convincing evidence of syntectonic emplacement and crystallization (following the criteria defined by Paterson et al. 1998). This second event must have terminated before the crystallization of the ultrapotassic (durbachite) intrusions, which were emplaced post-tectonically into the marginal part of the Strážek Unit at 339 Ma.

\section{Conclusions}

The following conclusions concerning the regional tectonometamorphic evolution were reached:

- The HT/HP tectonometamorphic event ( 340 Ma) was followed by HT decompression and polyphase exhumation of deep-seated rocks in the NE part of the Moldanubian Zone (Strážek Unit).

- In contrast, in the Kutná Hora Unit exhumation processes probably took place earlier - at $\sim 350 \mathrm{Ma}$. This unit
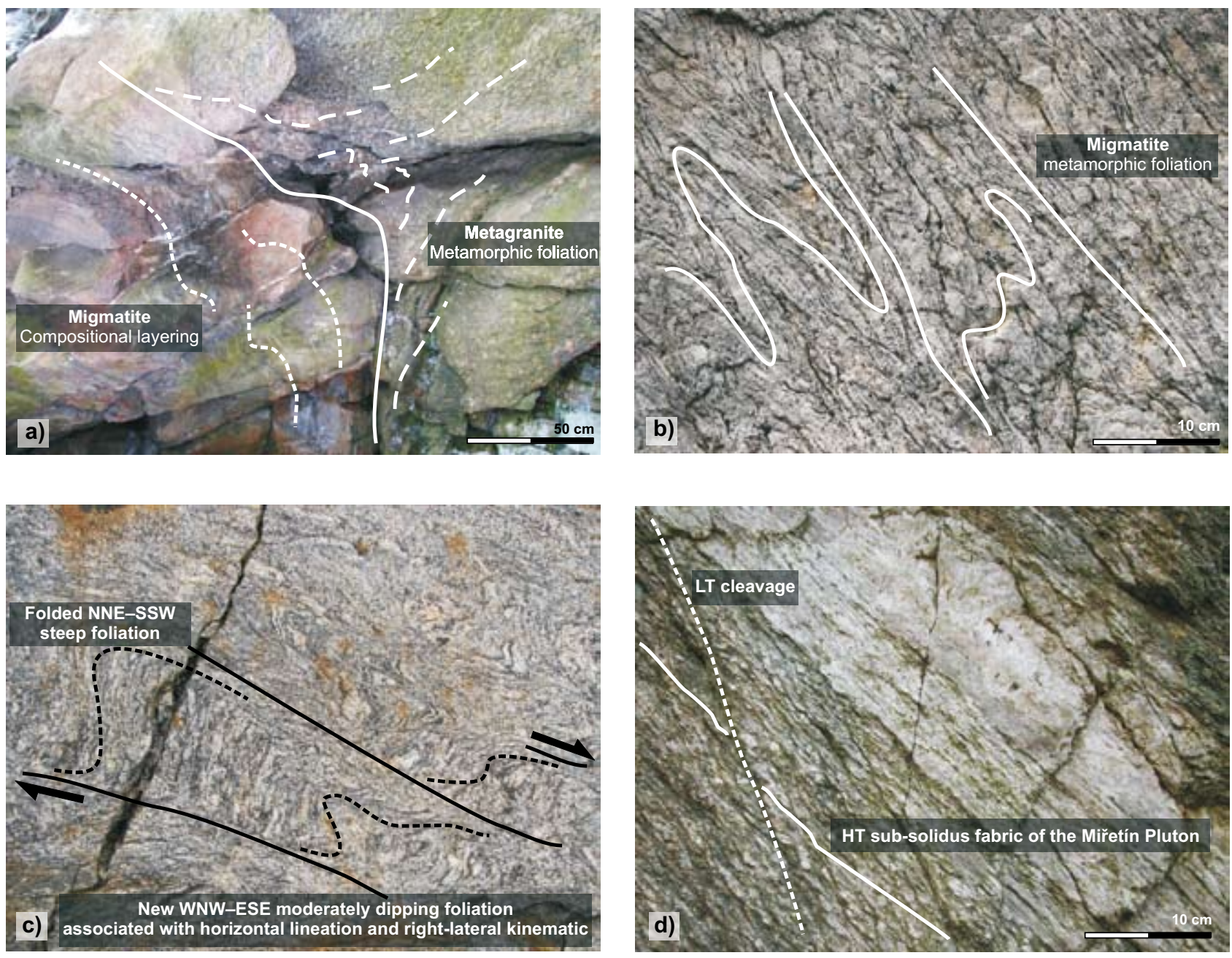

Fig. 6 Field photographs of fabric relationships. a - A stoped block of leucocratic migmatite in the metagranite of Cambro-Ordovician age (western part of the Svratka Unit; locality Zkamenělý Zámek near Svratka). b - Small isoclinal folds as relicts of older metamorphic fabric (eastern part of the Svratka Unit; locality: Bystřice nad Pernštejnem). c - Relationships of two regional metamorphic fabrics in the NE part of Moldanubian Zone (Strážek Unit; locality: Nové Město na Moravě quarry). d - The evidence of low-temperature cleavage superimposed on regional high-temperature solid-state fabric (western part of the Miřetín Pluton, Polička Unit; locality: Otradov) 
was not affected by LP/HP Variscan decompressional recrystallization.

- The "long-lived" regional tectonometamorphic evolution ( 350-339 Ma) in the mid- to upper-crustal part of the Polička and Zábřeh units (all interpreted as representing the eastern prolongation of the Teplá-Barrandian Unit) reflects right-lateral strike-slip shearing (transpressional to transtensional tectonics) at an approximate depth of $\sim 18 \mathrm{~km}$.

- The calc-alkaline plutons were emplaced syntectonically in upper- to mid-crustal rocks of the Polička and Zábřeh units during the formation of these regional metamorphic fabrics at around $350 \mathrm{Ma}$. In this context, the calc-alkaline intrusions are excellent time-markers of regional transpressional to transtensional geodynamic events in the mid- to upper-crustal segment of this part of the Variscan belt.

- The latest structural stages were connected with formation of extensive localized brittle-ductile shear zones and faults (e.g., NNE-SSW boundary between the Polička and Hlinsko units).

The broad relationships of the described structures provide important constraints for the kinematic framework and timing of the geodynamic processes involving the different segments of the Variscan orogenic crust along the NE periphery of the Moldanubian Zone.

Acknowledgements This research was funded by Czech Geological Survey Research Project No. 6352 (to Jaroslava Pertoldová) and Grant Agency of Charles University No. 81909 (to Lukáš Vondrovic). The thorough reviews and constructive comments by the handling editor Vaclav Kachlík, Fritz Finger and two anonymous reviewers helped to improve the manuscript and are gratefully acknowledged.

\section{References}

Anczkiewicz R, Szczepański J, Mazur S, Storey CD, Crowley Q, Villa IM, Thirlwall MF, JefFries ET (2007) Lu-Hf geochronology and trace element distribution in garnet; implications for uplift and exhumation of ultrahigh pressure granulites in the Sudetes, SW Poland. Lithos 95: 363-380

BECKER H (1997) Sm-Nd garnet ages and cooling history of high-temperature garnet peridotite massifs and highpressure granulites from Lower Austria. Contrib Mineral Petrol 127: 224-236

Bröcker M, Klemd R, Cosca M, Brock W, Larionov A N, RoDionOv N (2009) The timing of eclogite facies metamorphism and migmatization in the Orlica-Snieznik complex, Bohemian Massif: constraints from a multimethod geochronological study. J Metamorph Geol 27: 385-403
Brueckner K, Blusztajn J, Bakun-Czubarow N (1996) Trace element and Sm-Nd 'age' zoning in garnets from peridotites of the Caledonian and Variscan mountains and tectonic implications. J Metamorph Geol 14: 61-73

Buriánek D, NĚMečKovÁ M, Hanžl P (2003) Petrology and geochemistry of plutonic rocks from the Polička and Zábřeh crystalline units (NE Bohemian Massif). Bull Czech Geol Surv 78: 9-22

Buriánek D, Verner K, Hanžl P, Krumlová H (2009) Petrochemical and microstructural comparison between Cambro-Ordovician metagranites and migmatites of the Svratka Unit and the Orlice-Sněžník Unit. J Geosci 54: 181-200

Cháb J, Stráník Z, Eliáš M, Adamovič J, Babưrek J, Breiter K, Cajz V, DomečKa K, Fišera M, Hanžl P, Holub V, Hradecký P, Chlupáč I, Klomínský J, Mašek J, Mlčoch B, Opletal M, Otava J, Pálenský P, Prouza V, RŮŽıčKa M, SchováNeK P, SlabÝ J, VALEČKA J, Ž́̇ČEK V (2007) Geological map of Czech Republic 1 : 500000 (uncovered). Czech Geological Survey, Prague, ISBN 978-80-7075-699-7

Chaloupský J, Chlupáč I, Mašek J, Waldhausrová J, CháB J (1995) Teplá Barrandian Zone (Bohemicum) - Stratigraphy (Chapter VII.B.1). In: DALLMEYER RD, FRANKE W, Weber K (eds) Pre-Permian Geology of Central and Eastern Europe. Springer-Verlag, Berlin, pp 379-392

Cymerman Z, Piasecki A J, Seston R (1997) Terranes and terrane boundaries in the Sudetes, Northeast Bohemian Massif. Geol Mag 134: 717-725

DÖRR W, ZuLAUF G (in print) Elevator tectonics and orogenic collapse of a Tibetan-style plateau in the European Variscides: the role of the Bohemian shear zone. Int J Earth Sci (Geol Rundsch) DOI 10.1007/s00531-008-0389-x

DrÁBEK M, STEIN H (2003) The age of formation of a marble in the Moldanubian Varied Group, Bohemian Massif, Czech Republic using Re-Os dating of molybdenite. In: Eliopoulos CJ, Spry P, Stein H, Beaudoin G (eds) Mineral Exploration and Sustainable Development. Millpress, Rotterdam, pp 973-976

Drost K, Linnemann U, McNaughton N, Fatka O, Kraft P, Gehmlich M, Tonk Ch, Marek J (2004) New data on the Neoproterozoic-Cambrian geotectonic setting of the Teplá-Barrandian volcano-sedimentary successions: geochemistry, $\mathrm{U}-\mathrm{Pb}$ zircon ages, and provenance (Bohemian Massif, Czech Republic). Int J Earth Sci 93: 742-757

Fajst M (1976) A new unconformity in the Precambrian of the Bohemian Massif. Čas Min Geol 21: 257-275 (in Czech)

Fiala J, Fuchs G, Wendt I (1995): Moldanubian Zone - Stratigraphy (Chapter VII.C.1). In: DALlmeYer RD, Franke W, Weber K (eds) Pre-Permian Geology of Central and Eastern Europe. Springer-Verlag, Berlin, pp 417-428 
Finger F, Roberts MP, Haunschmid B, Schermaier A, SteyRER HP (1997) Variscan granitoids of Central Europe: their typology, potential sources and tectonothermal relations. Mineral Petrol 61: 67-96

Finger F, Hanžl P, Pin C, von Quadt A, Steyrer H P (2000) The Brunovistulian: Avalonian Precambrian sequence at the eastern end of the Central European Variscides? In: Franke W, HaAk V, Oncken O, Tanner D (eds) Orogenic Processes: Quantification and Modelling in the Variscan Belt. Geol Soc London Spec Publ 179: pp 103-112

FIŠERA M (1977) Geology and petrology of the Kutná Hora Unit west of Kolín. Czech Geological Survey Research Papers 16: 19-31 (in Czech)

Franke W (2000) The mid-European segment of the Variscides: tectonostratigraphic units, terrane boundaries and plate tectonic evolution. In: Franke W, HAAK W, Oncken O, TANner D (eds) Orogenic Processes: Quantification and Modelling in the Variscan Belt. Geol Soc London Spec Publ 179: 35-63

Franke W, ŻELAŹNIEWICZ A (2000) The eastern termination of the Variscides; terrane correlation and kinematic evolution. In: Franke W, HaAK W, Oncken O, TANner D (eds) Orogenic Processes: Quantification and Modelling in the Variscan Belt. Geol Soc London Spec Publ 179: 63-86

Friedl G, Finger F, Paquette JL, von Quadt A, McNaughTON NJ, Fletcher IR (2004) Pre-Variscan geological events in the Austrian part of the Bohemian Massif deduced from U-Pb zircon ages. Int J Earth Sci 93: 802-823

HanžL P, BuriánKová K, KabÁtník P, Finger F (2000) The results of geological mapping of western part of Zábřeh Unit. Geol výzk Mor a Slez v r 1999, pp 116-119 (in Czech)

Hanžl P, Buriánková K, BeŠTa J, BlažKová Š, BŘízová E, Dosbaba M, Fürych V, Kirchner K, Kryštofová E, LySenko V, Pertoldová J, Roštínský P, RÝda K, Skácelová D, SkÁcelová Z, Vít J, ZavŘElovÁ A, ŽÁčKovÁ E (2008) Basic geological map ČR 1:25 000 with explanations, 24113 Nové Město na Moravě. Czech Geological Survey, Prague, pp 1-79 (in Czech)

Hanžl P, Buriánek D, Čurda J, Fürich V, Hrdličková K, Kirchner K, Lysenko V, Mrnková J, Otava J, PerTOldová J, Roštínský P, RÝda K, SkÁcelová Z, Vít J, ZELENKA P (2008) Basic geological map ČR 1:25 000 with explanations, 14-333 Svratka. Czech Geological Survey, Prague, pp 1-72 (in Czech)

Hegner E, Kröner A (2000) Review of Nd isotopic data and xenocryst and detrital zircon ages from the pre-Variscan basement in the eastern Bohemian Massif: speculations on palinspasic reconstructions. In: FrANKE W, HAAK W, Oncken O, Tanner D (eds) Orogenic Processes: Quantification and Modelling in the Variscan Belt. Geol Soc London Spec Publ 179: pp 113-129
JANOUŠEK V, HoLuB F V (2007) The causal link between HPHT metamorphism and ultrapotassic magmatism in collisional orogens: case study from the Moldanubian Zone of the Bohemian Massif. Proc Geol Assoc 118: 75-86

Janoušek V, Vrána S, Erban V, Vokurka K, Drábek M (2008) Metabasic rocks in the Varied Group of the Moldanubian Zone, southern Bohemia - their petrology, geochemical character and possible petrogenesis. J Geosci 53: 31-64

JASTRZĘBSKI M (in print) A Variscan continental collision of the West Sudetes and the Brunovistulian Terrane: a contribution from structural and metamorphic records of the Stronie Formation, the Orlica-Śnieżnik Dome, SW Poland. Int J Earth Sci DOI 10.1007/s00531-008-0357-5

KACHLÍK V (1999) Relationship between Moldanubicum, the Kutná Hora crystalline Unit and Bohemicum (central Bohemia, Czech Republic): a result of the polyphase Variscan nappe tectonics. J Czech Geol Soc 44: 201-291

Kodym O, Svoboda J (1950) The report about geological mapping around Jevíčko, Letovice and Polička. Věst Stát geol úst 25: 109-160 (in Czech)

Kröner A, ŠtíPSKÁ P, Schulmann K, Jaeckel P (2000a) Chronological constraints on the pre-Variscan evolution of the northeastern margin of the Bohemian Massif, Czech Republic, In: Franke W, HaAk W, Oncken O, TANNER D (eds) Orogenic Processes: Quantification and Modelling in the Variscan Belt. Geol Soc London Spec Publ 179: pp 175-198

Kröner A, O’Brien PJ, Nemchin AA, Pidgeon R T (2000b) Zircon ages for high pressure granulites from South Bohemia, Czech Republic, and their connection to Carboniferous high temperature processes. Contrib Mineral Petrol 138: 127-142

Kröner A, Jaeckel P, Hegner E, Opletal M (2001) Single zircon ages and whole rock $\mathrm{Nd}$ isotopic systematics of early Palaeozoic granitoid gneisses from the Czech and Polish Sudetes (Jizerské hory, Krkonoše Mountains and Orlice-Sněžník Complex). Int J Earth Sci 90: 304-324

Kröner U, Mansy J L, Mazur S, Aleksandrowski P, Hann H P, Huckriede H, Lacquement F, Lamarche J, Ledru P, Pharaoh T C, Zedler H, Zeh A, Zulauf G (2008) Variscan tectonics. In: McCANN T (ed) The Geology of Central Europe, Vol 1. Geological Society of London Special Publication, pp 599-665

Kryza R, Pin C, Vielzeuf D (1996) High-pressure granulites from the Sudetes (south-west Poland): evidence of crustal subduction and collisional thickening in the Variscan Belt. J Metamorph Geol 14: 531-546

Linnemann U, Pereira F, Jeffries T E, Drost K, Gerdes A (2008) The Cadomian Orogeny and the opening of the Rheic Ocean: the diacrony of geotectonic processes constrained by LA-ICP-MS U-Pb zircon dating (OssaMorena and Saxo-Thuringian zones, Iberian and Bohemian massifs), Tectonophysics 461: 21-43 
LINNER M (1996) Metamorphism and partial melting of paragneisses of the Monotonous Group, SE Moldanubicum (Austria). Mineral Petrol 58: 215-234

LOSERT J (1956a) Report about detailed geological mapping in the NW part of Kutná Hora ore district. Zpr geol výzk v R 1955: 99-101 (in Czech)

LOSERT J (1956b) Dumortierites from the migmatites and pegmatites in the vicinity of Kutná Hora. Rozpr Čs Akad Věd, ř Mat Př́r Věd 66: 1-44

LOSERT J (1967) Contribution to the problem of the preAssyntian tectogenesis and metamorphism in the Moldanubicum of the Bohemian Massif. Krystalinikum 5: $61-84$

Mazur S, Aleksandrowski P, Szczepański J (2005) The presumed Teplá-BarrandianMoldanubian terrane boundary in the Orlica Mountains (Sudetes, Bohemian Massif): structural and petrological characteristics. Lithos 82: 85-112

Mazur S, Aleksandrowski P, Kryza P, Oberc-Dziedzic T (2006) The Variscan orogen in Poland. Geol Quart 50: $89-118$

Medaris LG JR, Jelínek E, Mísař Z (1995) Czech eclogites: terrane settings and implications for Variscan tectonic evolution of the Bohemian Massif. Eur J Mineral 7: $7-28$

Melichar R (1995) The structural analysis of the Polička and Svratka units. Unpublished $\mathrm{PhD}$ thesis, Charles University, Prague, pp 1-271 (in Czech)

Melichar R (2004) Tectonics of the Prague Synform; a hundred years of scientific discussion. Krystalinikum 30: $167-187$

Melichar R, Buriánek D, Břizová E, Buriánková K, ČURda J, FÜRYCh V, HanžL P, KirChNer K, Lysenko V, Mrnková J, Roštínský P, RÝda K, Skácelová Z, Vít J (2008) Explanations to the geological map ČR 1:25 000, 24-111 Sněžné. Czech Geological Survey Prague, pp 1-58 (in Czech)

Mísař Z, Dudek A (1993) Some critical events in the geological history of eastern margin of the Bohemian Massif. J Czech Geol Soc 38: 9-20

NĚMEC D (1998) Highly mafic amphibolites in the Moldanubian Zone of the Bohemian-Moravian Heights (Českomoravská vrchovina). Acta Mus Moraviae, Sci Nat 83: 59-71

Owen JV, Dostal J (1996) Contrasting corona structures in mafic granulite from the Blanský Les complex, Bohemian Massif, Czech Republic. Canad Mineral 34: 959-966

Paterson SR, Fowler TK, Schmidt KL (1998) Interpreting magmatic fabric patterns in plutons. Lithos 44: 53-82

Pertoldová J (1986) Conditions of Genesis of Skarns at Pernštejn, Županovice and Nové Město pod Smrkem Deposits. Unpublished $\mathrm{PhD}$ thesis, Charles University, Prague, pp 1-86 (in Czech)

Pertoldová J, Týcová P, Verner K, Košuličová M, Pertold Z, Košler J, Konopásek J, Pudilová M (2009) Metamor- phic history of skarns, origin of their protolith and implications for genetic interpretation; an example from three units of the Bohemian Massif. J Geosci 54: 101-134

Pitra P, Burg J P, Schulmann K, Ledru P (1994) Late-orogenic extension in the Bohemian Massif: petrostructural evidence in the Hlinsko region. Geodin Acta 6: 15-31

Pitra P, Guiraud M (1996) Probable anticlockwise P-T evolution in extending crust: Hlinsko region, Bohemian Massif. J Metamorph Geol 14: 49-60

Racek M, ŠTí́ská P, Pitra P, Schulmann K, Lexa O (2006) Metamorphic record of burial and exhumation of orogenic lower and middle crust: a new tectonothermal model for the Drosendorf Window (Bohemian Massif, Austria). Mineral Petrol 86: 221-251

SCHUlMANN K, GAYER R (2000) A model for a continental accretionary wedge developed by oblique collision: the NE Bohemian Massif. J Geol Soc, London 157: 401-416

Schulmann K, Ledru P, Autran A (1991) Evolution of nappes in the eastern margin of the Bohemian Massif: a kinematic interpretation. Geol Rundsch 80: 73-92

Schulmann K, Kröner A, Hegner E, Wendt I, Konopásek J, LeXA O, ŠTíPSKÁ P (2005) Chronological constraints on the pre-orogenic history, burial and exhumation of deep-seated rocks along the eastern margin of the Variscan orogen Bohemian Massif, Czech Republic. Amer J Sci 305: 407-448

Schulmann K, Lexa O, Štípská P, Racek M, Tajčmanová L, Konopásek J, Edel JB, Peschler A, Lehmann J (2008) Vertical extrusion and horizontal channel flow of orogenic lower crust: key exhumation mechanisms in large hot orogens? J Metamorph Geol 26: 273-297

Schulmann K, Konopásek J, Janoušek V, Lexa O, Lardeaux JM, Edel JB, ŠTíPská P, UlRich S (2009) An Andean type Palaeozoic convergence in the Bohemian Massif. C R Geosci 341: 266-286

Synek J, Oliveriová D (1993) Terrane character of the northeast margin of the Moldanubian Zone: the Kutná Hora Crystalline Complex, Bohemian Massif. Geol Rundsch 82: $566-582$

ŠTíPSKÁ P, SChulmann K, KRÖNer A (2004) Vertical extrusion and middle crustal spreading of omphacite granulite: a model of syn-convergent exhumation (Bohemian Massif, Czech Republic). J Metamorph Geol 22: 179-198

Štoudová S, Schulmann K, KonopÁseK J (1999) The contrast between metamorphic and structural evolution of the Vír Granulite and surrounding metapelites of the Polička Crystalline Unit. Terra Nostra 99: 191-193

Tajčmanová L, KonopáseK J, Schulmann K (2006) Thermal evolution of the orogenic lower crust during exhumation within a thickened Moldanubian root of the Variscan belt of Central Europe. J Metamorph Geol 24: 119-134

Urban M, Synek J (1995) Moldanubian Zone - Structure (Chapter VII.C.2). In: DaLLMEYer RD, Franke W, Weber $\mathrm{K}$ (eds) Tectonostratigraphic Evolution of the Central 
and East European Orogens. Springer-Verlag, Berlin, pp 429-443

VACHTL J (1962) The Hlinsko Palaeozoic and its relationship to neighbouring units. Sbor Ústř úst geol 27: 341-359 (in Czech)

Verner K, Ž́́́ J, Nahodilová R, Holub FV (2008) Magmatic fabrics and emplacement of the cone-sheet-bearing Knížecí Stolec durbachitic pluton (Moldanubian Unit, Bohemian Massif): implications for mid-crustal reworking of granulitic lower crust in the Central European Variscides. Int J Earth Sci 97: 19-33

VondRovic L, Verner K (2008) The record of structural evolution and $\mathrm{U}-\mathrm{Pb}$ zircon dating of the tonalite intrusions (Polička Crystalline Unit, Bohemian Massif). In: Poblet J, Medina MG, Pedreira D, Fernández CL (eds) International Meeting of Young Researches in Structural Geology and Tectonics - Programme and Extended abstracts, University of Oviedo, Spain, pp 369-373

VRána S, Blümel P, Petrakakis K (1995) Moldanubian Zone - Metamorphic Evolution (Chapter VII.C.4). In: Dallmeyer RD, Franke W, Weber K (eds) Pre-Permian
Geology of Central and Eastern Europe. Springer-Verlag, Berlin, pp 453-468

VRána S, Štědrá V, Milan Fišera M (2005) Petrology and geochemistry of the Běstvina granulite body metamorphosed at eclogite facies conditions, Bohemian Massif. J Czech Geol Soc 50: 95-106

VRÁNA S, ŠTĚDRÁ V, NAHODILOVÁ R (2009) Geochemistry and petrology of high-pressure kyanite-garnet-albite-K-feldspar felsic gneisses and granulites from the Kutná Hora Complex, Bohemian Massif. J Geosci 54: 159-179

WeIss J (1992) Oceanic crustal relicts in the continental lithosphere of Czechoslovakia. Krystalinikum 21: $89-100$

Wendt J, Kröner A, Fiala J, Todt W (1993) Evidence from zircon dating for existence of approximately $2.1 \mathrm{Ga}$ old crystalline basement in Southern Bohemia, Czech Republic. Geol Rundsch 82: 42-50

Zavřelová A, Melichar R, Soejono i, Verner K, TAJČMANOVÁ L (2006) Tectonometamorphic evolution of the Svratka Crystalline Complex (NE): evidence for wrench-dominated transpression along the NE margin of the Variscan orogenic root. Geolines 20: 138 